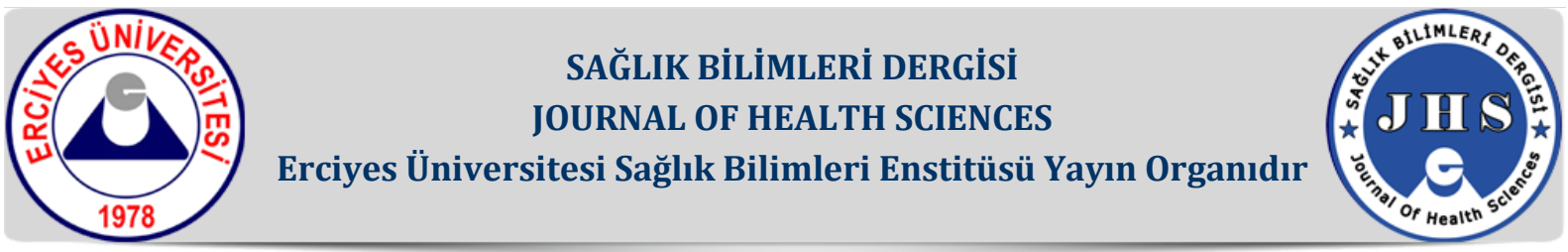

Araştırma Yazısı

2021; 30: 113-117

\title{
INVESTIGATION OF ENZYME INHIBITORY PROPERTIES AND ANTIOXIDANT ACTIVITY OF CAPPARIS OVATA DESF. VAR. PALAESTINA ZOH. FLOWER AND FRUIT EXTRACTS \\ CAPPARIS OVATA DESF. VAR. PALAESTINA ZOH. BITTKISININ ÇIÇEK VE MEYVE EKSTRELERININN ENZIM İNHİBITÖR ÖZELLIKKLERİ VE ANTİOKSIDDAN ETKİLERINIIN ARAŞTIRILMASI
}

\section{Leyla PAŞAYEVA' ${ }^{1}$ Ayşe Kübra KARABOĞA ARSLAN²}

${ }^{1}$ Erciyes University, Faculty of Pharmacy, Department of Pharmacognosy, Kayseri

${ }^{2}$ Erciyes University, Faculty of Pharmacy, Department of Pharmacology, Kayseri

\begin{abstract}
In this study, the inhibiting effect on $\alpha$-amylase and $\alpha$ glucosidase and the antioxidant activity of ethanol extracts from flower and fruit of Capparis ovata var. $p a-$ laestina was investigated. The antioxidant activity of the extracts was tested with DPPH $\bullet$, ABTS $\bullet+$ and FRAP methods. According to the results, the highest $\alpha$ glucosidase and $\alpha$-amylase activity were found in fruit extract $\left(\mathrm{IC}_{50}=271.72 \pm 0.41\right.$ and $142.07 \pm 0.85 \mu \mathrm{g} / \mathrm{mL}$, respectively). Also, the highest TPC $(26.40 \pm 0.02 \mathrm{mgGAE} /$ gextract) and TFC $(8.33 \pm 0.30 \mathrm{mgCA} /$ gextract $)$ were found in the same extract and this extract showed the highest DPPH $\bullet$ activity (32\%). Although, flower extract showed the highest FRAP values (at a concentration of 1 $\mathrm{mg} / \mathrm{mL}$ equivalent to $262.69 \pm 2.27 \mathrm{mmol} \mathrm{Fe}^{2+}$ ) and ABTS + (at a concentration of $0.5 \mathrm{mg} / \mathrm{mL}$ equivalent to $0.18 \pm 0.01 \mu \mathrm{M}$ Trolox) activity. In conclusion, it is thought that these studies will shed light on future studies on this species.
\end{abstract}

Keywords: Capparaceae, diabetes, DPPH, $\alpha$-amylase, $\alpha$-glucosidase.

\section{ÖZ}

Bu çalışmada Capparis ovata var. Palaestina bitkisinin çiçek ve meyvelerinden hazırlanan etanol ekstresinin $\alpha$ amilaz ve $\alpha$-glikozidaz inhibitor etkisi ve antioksidan özelliği araștırılmıştır. Ekstrelerin antioksidant etkisi DPPH•, ABTS ${ }^{\bullet}$ ve FRAP testleri kullanılarak değerlendirilmiştir. Sonuçlara gore en yüksek $\alpha$-amilaz ve $\alpha$ glikozidaz etki meyve ekstresinde bulunmuștur (sirasiyla, $\mathrm{IC}_{50}=271.72 \pm 0.41$ ve $142.07 \pm 0.845 \mu \mathrm{g} / \mathrm{ml}$ ). Ayrıca en yüksek TPC $\left(26.40 \pm 0.02 \mathrm{mgGAE} / \mathrm{g}_{\text {extract }}\right)$ ve TFC $\left(8.33 \pm 0.30 \mathrm{mgCA} / \mathrm{g}_{\text {extract }}\right)$ değerleri ve $\mathrm{DPPH} \bullet(\%$ 32) etkisi de aynı ekstrede görülmüştür. Bununla birlikte çiçek ekstresi en yüksek FRAP değerleri (1 mg/ ml konsantrasyonda $262.69 \pm 2.27 \mathrm{mmol} \mathrm{Fe}^{2+}$ eșdeğer] ve $\mathrm{ABTS}^{+} \bullet(0.5 \mathrm{mg} / \mathrm{ml}$ konsantrasyonda $0.18 \pm 0.01 \mu \mathrm{M}$ Troloks'a eşdeğer) aktivite göstermiștir. Sonuç olarak, yapılan çalışmanın bu bitki üzerinde ileride yapılacak çalışmalara ışık tutacağı düşünülmektedir.

Anahtar kelimeler: Capparaceae, diyabet, DPPH, $\alpha$ amilaz, $\alpha$-glikozidaz.
Corresponding Author: Dr. Öğr. Üyesi Leyla PAŞAYEVA, Department of Pharmacognosy, Faculty of Pharmacy, Erciyes University, Kayseri 38030, Turkey. ORCID ID:0000-0003-3860-7222

E-mail: leylapasayeva@erciyes.edu.tr Telefon: +90-352-207-6666 / 28277

Ayşe Kübra KARABOĞA ARSLAN, aysekubra@erciyes.edu.tr, ORCID: 0000-0002-4689-0657 


\section{INTRODUCTION}

Diabetes mellitus (DM) is a group of complex and chronic metabolic disorders with diverse multiple etiologies. It is characterized by high blood glucose (hyperglycemia) resulting from malfunction in insulin secretion and/or insulin action, both leading to impair metabolism of carbohydrates, lipids and proteins. The alterations in the utilization of complex biomolecules by the most affected tissues (liver, muscle and adipose tissue) due to hyperglycemia initiate a sequence of oxidative processes that cause dysfunction and failure of other organs in the body. Long-term complications may affect the organs such as kidneys, eyes, nerves, heart and blood vessels, and in absence of effective treatment result into death $(1,2)$.

At present, different approaches are used to control diabetes using modern synthetic anti-diabetic drugs, insulin injection and life style modification. The synthetic anti-diabetic drugs include sulphonylureas, glucosidase inhibitors, dipeptidyl peptidase-4 (DPP-4) inhibitors and biguanide. However, these synthetic drugs have characteristic profiles of serious side effects, which include hypoglycemia, weight gain, gastrointestinal discomfort and nausea, liver and heart failure, and diarrhoea $(3,4)$.

These limitations coupled with an exponential increase in the prevalence of diabetes motivate researchers to scientifically validate the folkloric use of a number of medicinal plants and/or their isolated bioactive compounds as possible alternative therapies for diabetes. Capparis L. is one of the widespread genus of the Capparaceae family. The Caper (Capparis) is known as kapari, keper, kebere, and gevil in different regions of Turkey (5). There are two species in Turkey (C. spinosa L. and C. Ovate Desf.) and each species is represented by three varieties as C. spinosa L. var. spinosa L., C. spinosa L. var. inermis Turra., C. spinosa L. var. aegyptia (Lam) Boiss, $C$. ovataDesf. var. palaestina Zoh., C. Ovate Desf. var. herbacea (Wild) Zoh. and $C$. ovate Desf. var. canescens (Coss.) Heywood (6). Caper which is an economically valuable plant is being used for food, drug and cosmetic purposes (5). Additionally, there are various studies on $C$. ovata as antidiabetic (6), antioxidant $(6,5)$, hepatoprotective(7), anticancer (8), wound healing (9), anti-neuro inflammatory $(10)$ and antinociceptive $(11,12)$ effects. The traditional uses have also been reported in literature (13). It was reported that different Caper species contained bioactive compounds such as glucosinolates, alkaloids, flavonoids and phenolic acids which are mediated by biological activities $(11,14)$.

There are some studies on hypoglicemic and antioxidant activity of different $C$. ovata var. Palaestina extracts generally performed. In this study, it was planned to investigate the inhibiting effect on digestive enzymes correlated to diabetes and antioxidant effects of $70 \%$ ethanol extracts of flower and fruits by soxhlet extraction. In this research, the inhibitory activity was carried out by $\alpha$-amylase and $\alpha$-glucosidase enzyme inhibitory assays and the antioxidant capacity was performed by radical scavenging activity (DPPH $\bullet, \mathrm{ABTS}^{+} \bullet$ and FRAP methods).

Once the extracts are obtained from the $C$. ovata var. palaestina, the next step is to subject the extracts to some in vitro bioassay protocols in order to examine whether the extracts are active or not. In vitro assays are usually faster, specific and not much amount of the extracts are used. Furthermore, some of the in vitro methods employed include chemical and enzymatic procedures, which depend on spectrophotometric analysis. For instance, in evaluating plants as possible anti-diabetic drugs, several in vitro models are used to assess the anti-diabetic effects and mode of actions as well. These models include enzyme inhibition-based assays (e.g. $\alpha$-amylase, $\alpha$ glucosidase and glucose 6-phosphatase inhibitions), glucose uptake bioassays (using cell lines such as C2C12 myocytes, 3T3-L1 pre-adipocytes and human Chang liver cells) and stimulation of insulin release (15). In in vivo approach, animals are used to investigate the efficacy, mode of action and side effects of the plant extracts. Furthermore, in DM, several models are employed. These include chemically induced animal models such as alloxan and streptozotocin-induced diabetic animals that are mostly used for the induction of T1D (16). In this study fruit extracts were found most active in vitro tests and may be recommended for in vivo tests.

\section{MATERIALS AND METHODS \\ Chemicals}

Chromatographic grade distilled water, HPLC grade methanol analytical grade formic acid was used for HPLC analyses.

\section{Plant Material and Preparation of Extracts}

C. ovata var. palaestina flower (500 g) and fruits (500 g) were harvested in August from Akpınar Village in Adıyaman Province, which is located within the borders of Turkey. The plant material was identified with AEF No 26797 herbarium voucher. After drying under suitable conditions, the dried flowers and fruits were pulverized and extracted separately using $70 \%$ ethanol $(2.5 \mathrm{~L})$ in soxhlet (continuous extraction) apparatus for $8 \mathrm{~h}$. The extracts were evaporated in a rotavapor under reduced pressure at $38^{\circ} \mathrm{C}$ and the obtained crude extracts as C. ovata var. palaestina flower extract (CFW) and fruit extract (CFR) were stored in dark at $-20^{\circ} \mathrm{C}$.

\section{The Enzyme Inhibition Assay}

The $\alpha$-glucosidase and $\alpha$-amylase inhibitory assay was established according to the method described by Paşayeva et al., (17). The extracts were tested in 37-1200 $\mu \mathrm{g} /$ $\mathrm{mL}$ concentrations. The $50 \mu \mathrm{L}$ of enzyme solution were added on various concentrations of extract solution (50 $\mu \mathrm{L}$ ) and were preincubated at $37^{\circ} \mathrm{C}$ for $10 \mathrm{~min}$. Then the $50 \mu \mathrm{L}$ of $5 \mathrm{mM}$ PNPG was added and the enzymatic reaction was initiated. With the addition of $2 \mathrm{~mL}$ of $0.2 \mathrm{mM}$ $\mathrm{Na}_{2} \mathrm{CO}_{3}$ solution the reaction was stopped. The absorbance was read at $400 \mathrm{~nm}$.

The sample $(40 \mu \mathrm{L})$ concentrations were used between 4$2000 \mu \mathrm{g} / \mathrm{mL}$.In this assay porcine pancreatic $\alpha$-amylase solution was prepared in cold distilled water $(4 \mathrm{U} / \mathrm{mL})$. In this assay the dilution range of extracts/sub-extracts were between $4-2000 \mu \mathrm{g} / \mathrm{mL}$. The enzyme solution, extract or positive control acarboseand sodium phosphate buffer solution were mixed. After preincubation at $25^{\circ} \mathrm{C}$ the starch solution was added and held on at $25^{\circ} \mathrm{C}$ for $3 \mathrm{~min}$. Then the color reagent (dinitrosalicylic acid) was added and held on $85^{\circ} \mathrm{C}$ water bath for $15 \mathrm{~min}$. The absorbance was measured at $540 \mathrm{~nm}$.

The Total Phenolic (TPC) and Total Flavonoid Content (TFC) 
The TPC was described by the method of Paşayeva et al., (17). Folin-Ciocalteu reagent was used in this assay, and TPC was calculated as milligram ofgallic acid equivalents (GAE) per gram of extract. The TFC was performed by the method Paşayeva et al., (17). As described in this method, absorbance was measured at $510 \mathrm{~nm}$ and TFC was determined as milligram of catechin equivalent (CA) per gram of extract. The TPC and TFC tests were performed in triplicate.

\section{In vitro Antioxidant Capacity}

\section{The DPPH radical scavenging assay}

1,1-diphenyl-2-picrylhydrazyl radical (DPPH•) scavenging activity of samples were determined using the method of Gyamfi and Aniya (18). Stock solutions of samples were prepared in methanol at $4 \mathrm{mg} / \mathrm{mL}$ concentrations. Then the stock solutions were diluted to obtain working concentrations $(0.025,0.05,0.1,0.2,0.4,0.6,0.8,1$ and 2 $\mathrm{mg} / \mathrm{mL}$ ). A volume of $50 \mu \mathrm{L}$ of a sample concentration was mixed with $950 \mu \mathrm{L} 0.05 \mathrm{M}$ Tris-HCl buffer and $1 \mathrm{~mL}$ of $\mathrm{DPPH} \bullet$ reagent. After the incubation, the absorbance was read at $517 \mathrm{~nm}$. In this study, butylated hydroxyanisole (BHA) was the reference standard and all tests performed in triplicate. The \% inhibition was calculated using Equation (3).

$\%$ inhibition $=\left[\left(\mathrm{Abs}_{\text {control- }}\right.\right.$ Abs sample $) / \mathrm{Abs}$ control $\left.) \times 100\right]$ (3)

\section{The ABTS radical scavenging assay}

The ABTS $\bullet$ was performed according to the method of Paşayeva et al., (17). In this assay, the ABTS+ $\bullet$ working solution was diluted with methanol. Then fresh $2850 \mu \mathrm{L}$ of $\mathrm{ABTS}^{+} \bullet$ reagent was mixed with sample. Trolox was chosen as a positive control and the antioxidant capacity was determined as Trolox equivalent. The absorbance was read at $734 \mathrm{~nm}$.

\section{The FRAP assay}

The ferric reducing ability power (FRAP) test was described to the method by Paşayeva et al., (17). In this assay, absorbance was read at $593 \mathrm{~nm}$. The FRAP values were determined using $\mathrm{FeSO}_{4} \cdot 7 \mathrm{H}_{2} \mathrm{O}$ as a standard ferric reducing activity. The results were expressed as mmol of $\mathrm{Fe}^{2+}$ equivalents per $\mathrm{g}$ of extract/fraction weight $\left(\mathrm{mmol} \mathrm{Fe}^{2+} / \mathrm{g}\right)$

\section{Statistical Analysis}

All statistical analyses were conducted using GraphPad Prism Software Version 8.0 (La Jolla, CA, USA). The results were expressed as the mean \pm standard deviation

(SD). Statistically significant values were compared using one-way ANOVA with Multiple Comparison Test and $p$-values of less than 0.05 were considered statistically significant.

\section{RESULTS}

\section{The Enzyme Inhibitory Activity}

The results of $\alpha$-glucoside and $\alpha$-amylase inhibitory activities of extracts were given in Figure I. In this study $\alpha$-glucosidase inhibitory activity of CFR extract was found higher $(\mathrm{P}<0.000664)$ than the activity of CFW $\left(\mathrm{IC}_{50}=271.72 \pm 0.41 \mu \mathrm{g} / \mathrm{mL}\right)$. The results of $\alpha$-amylase inhibitory effect showed that among the extracts CFR possessed the highest inhibition effect $\left(\mathrm{IC}_{50}=\right.$ $142.07 \pm 0.85 \mu \mathrm{g} / \mathrm{mL}$ ) than acarbose as a positive control (Table I). According to results CFW extract showed \%42 $\alpha$-glucoside and \%32 $\alpha$-amylase inhibitory activities at 1200 and $2000 \mathrm{mg} / \mathrm{mL}$, respectively. The $\mathrm{IC}_{50}$ values for CFW did not calculated in these concentrations.

The Total Phenolic Content (TPC) and Total Flavonoid Content (TFC)

The results of extracts were listed in Table I. In this study, the highest TPC and TFC was found in CFR extract $\left(26.40 \pm 0.02 \mathrm{mgGAE} / \mathrm{g}_{\text {extract }}\right.$ and $\left.8.33 \pm 0.30 \mathrm{mgCA} / \mathrm{g}_{\text {extract }}\right)$ $(\mathrm{P}<0.001)$.

\section{Antioxidant Activity}

\section{The DPPH Radical Scavenging Capacity}

The results for DPPH $\bullet$ antioxidant capacity of extracts are presented in (Figure II). According to results CFR extract showed $32 \%$ antioxidant capacity and CFW extract 23\% DPPH radical scavenging capacity at 2000 $\mathrm{mg} / \mathrm{mL}$. None of the extracts showed high capacity than BHA as positive standart.

\section{The ABTS Radical Scavenging Activity}

The concentrations of samples and BHA were $0.5 \mathrm{mg} /$ $\mathrm{mL}$ to determine ABTS radical scavenging activity. According to the results, the CFW extract showed the highest activity $(0.18 \pm 0.01$ Trolox/gextract $)(\mathrm{P}<0.000360)$ (Table I).

\section{The FRAP Results}

The results were showed that, $\mathrm{CFW}$ extract was more active $\left(262.69 \pm 2.27 \mathrm{mmol} \mathrm{Fe}^{2+/ g}\right.$ extract $)(\mathrm{P}<0.000590)$ than CFR extract $\left(198.15 \pm 1.236 \mathrm{mmol} \mathrm{Fe}^{2+} / \mathrm{g}_{\text {extract }}\right)$. Trolox was used as a standard.

\section{DISCUSSION}

Table I. Total phenolic, total flavonoid content, antioxidant and enzyme inhibitory activity results of $C$. ovata var. palaestina extracts.

\begin{tabular}{|c|c|c|c|c|c|c|}
\hline Samples & $\begin{array}{c}\alpha \text {-glucosidase } \\
\text { assay IC } \mathrm{I}_{50}(\mu \mathrm{g} / \\
\mathrm{mL})\end{array}$ & $\begin{array}{c}\alpha \text {-amylase } \\
\text { assay } \mathrm{IC}_{50}(\mu \mathrm{g} / \\
\mathrm{mL})\end{array}$ & $\begin{array}{c}\text { TPC (mg } \\
\text { GAE / gextract) }\end{array}$ & $\begin{array}{r}\text { TFC (mg } \\
\text { CA / gextract) }\end{array}$ & $\begin{array}{c}\text { FRAP (mmol } \\
\mathbf{F e}^{2+} / \mathbf{g} \text { extract/ } \\
\mathbf{m m o l ~ F e}^{2+} /\end{array}$ & $\begin{array}{c}\text { ABTS }(\mu \mathrm{M} \\
\text { Trolox/gextract/ } \\
\mu \mathrm{M} \text { Trolox/ }\end{array}$ \\
\hline CFR & $142.07 \pm 0.85^{\mathrm{b}, \mathrm{a}}$ & $271.72 \pm 0.41^{\mathrm{c}, \mathrm{a}}$ & $26.40 \pm 0.02^{\mathrm{a}, \mathrm{d}}$ & $8.33 \pm 0.30^{c}$ & $198.15 \pm 1.24 c, d$ & $0.17 \pm 0.01^{\mathrm{c}, \mathrm{a}}$ \\
\hline CFW & - & - & $17.24 \pm 0.02^{\mathrm{d}, \mathrm{e}}$ & $7.73 \pm 0.15^{\mathrm{d}}$ & $262.69 \pm 2.27 \mathrm{~d}, \mathrm{e}$ & $0.18 \pm 0.01^{\mathrm{a}, \mathrm{e}}$ \\
\hline Trolox & - & - & - & - & $6235.01 \pm 1.63^{\mathrm{a}, \mathrm{b}}$ & - \\
\hline BHA & - & - & - & - & - & $0.73 \pm 0.01 \mathrm{~b}, \mathrm{a}$ \\
\hline Acarbose & $231.27 \pm 0.24^{\mathrm{a}}$ & $221.79 \pm 0.23^{\mathrm{a}}$ & - & - & - & - \\
\hline
\end{tabular}

Values are expressed as mean $\pm \mathrm{SD}(\mathrm{n}=3)$. CFR ethanol extract of $C$. ovata var. palaestina fruit, CFW ethanol extract of $C$. ovata var. palaestina flower. Values followed by the same letter are not significantly different $(\mathrm{P}<0.05)$. 

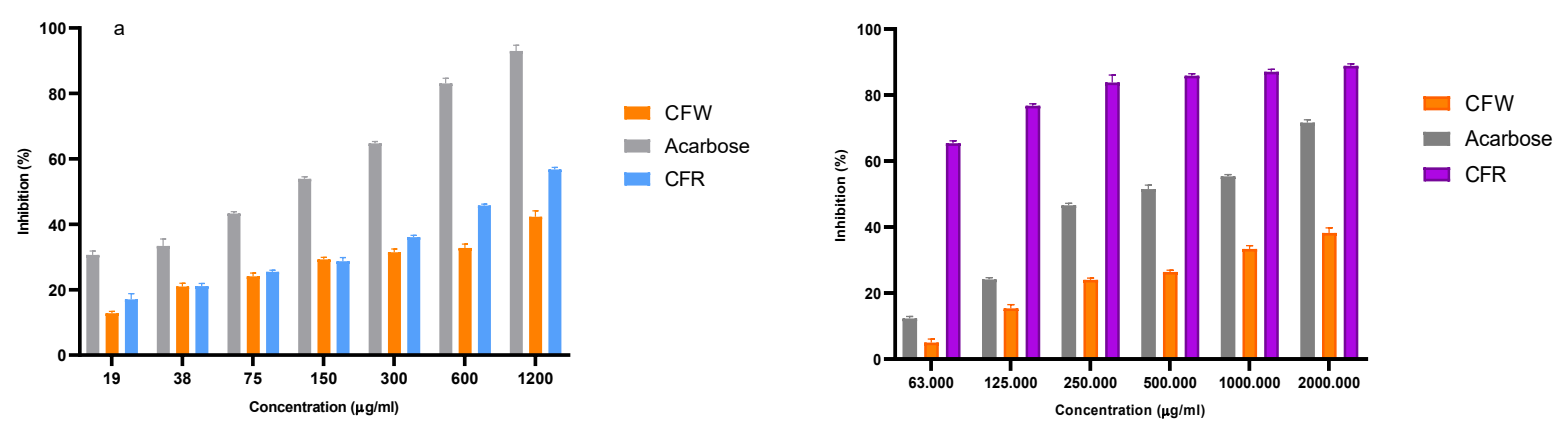

Figure I. $\alpha$-glucosidase (a) and $\alpha$-amylase (b) inhibitory activities of $C$. ovata var. palaestina extracts.

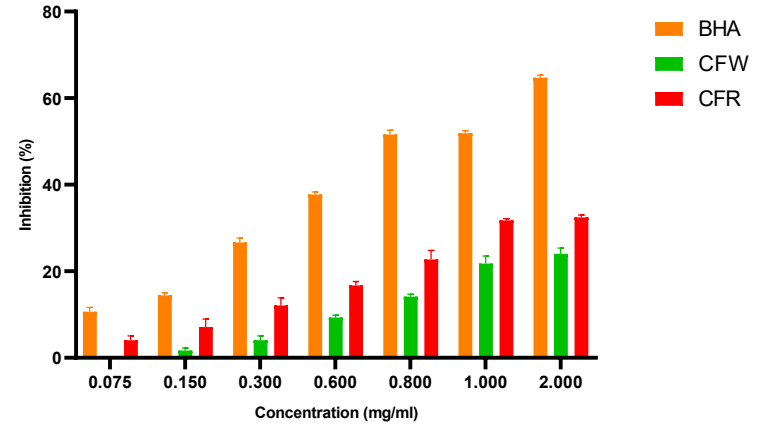

Figure II. DPPH radical scavenging capacities of $C$. ovata var. palaestina extracts.

It is known that more than 387 million people suffer from DM around the world. Type 2 diabetes is a type of DM and described by hyperglycemia. It is well known that type 2 diabetes is caused by reactive oxygen species (ROS) (19).

There are a numerous stuies on $\alpha$-glucosidase, $\alpha$ amylase inhibitory effects and antioxidant properties of C. ovata var. palaestina. The objective of this research is to evaluate the hypoglycemic activity by $\alpha$-glucosidase, $\alpha$-amylase methods and antioxidant activities of ethanol extracts of this plant prepared by soxhlet method.

In a study, the ethanol and aqueous extracts of $C$. ovata var. palaestina buds and fruits were administered intraperitoneally to alloxan-induced diabetic BALB-c mice with $100,300,500 \mathrm{mg} / \mathrm{kg}$ doses. As a result, significant hypoglycemic activity was found in fruit-aqueous extract thedose of $100 \mathrm{mg} / \mathrm{kg}, 300 \mathrm{mg} / \mathrm{kg}$ and bud-aqueous extract at $500 \mathrm{mg} / \mathrm{kg}$ doses. In the same study, the highest TPC and TFC was found in fruit-ethanol extract $(963.3 \pm 84.85 \mathrm{mg}$ GAE/100g Extract for TPC and $2785 \pm 21.21 \mathrm{mgQE} / 100 \mathrm{~g}$ Extract for TFC) and the highest antioxidant activity was determined in bud-aqueous extract $\left(\mathrm{IC}_{50}=0.4390 \pm 0.0105 \mathrm{mg} / \mathrm{mL}\right.$ for $\mathrm{DPPH}$ and $\mathrm{IC}_{50}=0.2139 \pm 0.006 \mathrm{mg} / \mathrm{mL}$ for ABTS) (5). In another study, the hypoglycemic effect of $C$. ovata var. palaestinaextracts was evaluated in alloxan-induced diabetic mice. For this purpose, diabetic mice were administered with $100,300,500 \mathrm{mg} / \mathrm{kg}$ (i.p.) doses of methanol extract of bud and fruit. The results revealed that fruitmethanol $500 \mathrm{mg} / \mathrm{kg}$, bud-methanol $300 \mathrm{mg} / \mathrm{kg}$, budmethanol $500 \mathrm{mg} / \mathrm{kg}$ extracts showed significant hypoglycemic activites. Furthermore, in this study the budmethanol extract was demonstrated the most potent antioxidant activity $\left(\mathrm{IC}_{50}=0.096 \pm 0.007 \mathrm{mg} / \mathrm{mL}\right.$ for
DPPH and $\mathrm{IC}_{50}=0.063 \pm 0.009 \mathrm{mg} / \mathrm{mL}$ for ABTS). Although, the highest TPC and TFC was found in fruitmethanol extract $(1017.42 \pm 44.18 \mathrm{mg}$ GAE$/ 100 \mathrm{~g}$ Extract for TPC and $2990 \pm 21.21 \mathrm{mgQE} / 100 \mathrm{~g}$ Extract for TFC) (6). Additionally, the anti-inflammatory effect, antimicrobial and antibacterial activity and wound healing properties of different extracts of $C$. ovata var. palaestina were investigated $(8,9,5)$.

In this study, the hypoglycemic and antioxidant activity of ethanol extract of $C$. ovata var. palaestina flower and fruits were investigated. The fruit extract was found the most active in term of $\alpha$-amylase and $\alpha$-glycosidase inhibition effect. By the same, the higher TPC and TFC and the DPPH radical scavenging activities were found in this extract. On the other hand, the highest FRAP values and ABTS activity were found in the flower extract. Some investigations showed that the high potent $\alpha$-amylase and $\alpha$-glycosidase inhibition and antioxidant activity were related to the high phenolic/ flavonoid content of extracts. Therefore, we can consider that the potent $\alpha$-amylase and $\alpha$-glycosidase inhibition and antioxidant activity of CFR extract may be explained by the presence of these compounds. According to the earlier studies $C$. ovata var. palaestina contained alkaloids, lipids, polyphenols, flavonoids, and glucosinolates (5). Considering the earlierstudies on anti-diabetic and antioxidant activities of the plant, it can be said that the phenolic compounds and flavonoids are responsible for these activities $(5,6,8,9)$.

\section{CONCLUSION}

In this study fruit extract was found the most active in terms of $\alpha$-amylase and $\alpha$-glucosidase inhibitory effect and the antioxidant activity. As a result, this extract can be considered a natural source for antioxidants and antidiabetic agents after the detailed investigation. Furthermore, the investigations are beneficial for the development of novel products in the pharmaceutical and food industries.

\section{Acknowledgments}

The authors are thankful to Kübra Olagan for providing plant material.

\section{REFERENCES}

1. Maritim AC, Sanders RA, Watkins JB 3rd. Diabetes, oxidative stress, and antioxidants: A review. J Biochem Mol Toxicol 2003; 17 (1):24-38.

2. Surampudi PN, John-Kalarickal J, Fonseca VA. Emerging concepts in the pathophysiology of type 
2 diabetes mellitus. Mt Sinai J Med 2009; 76 (3):216-226.

3. Hung HY, Qian K, Morris-Natschke SL, et al. Recent discovery of plant-derived anti-diabetic natural products. Nat Prod Rep 2012; 29(5):580-606.

4. Sloop KW, Michael MD, Moyers JS. Glucagon as a target for the treatment of type 2 diabetes. Expert Opin Ther Targets 2005; 9(3):593-600.

5. Okur ME, Polat DC, Ozbek H, et al. Evaluation of the antidiabetic property of Capparis ovata Desf. var. palaestina Zoh. Extracts using in vivo and in vitro approaches. Endocr Metab Immune Disord Drug Targets 2018; 18(5):489-501.

6. Okur ME, Özbek H, Polat DÇ, et al. Hypoglycemic activity of Capparis ovata Desf. var. Palaestina Zoh. methanol extract. Brazilian Journal of Pharmaceutical Sciences 2018; 54(3):1-9.

7. Aghel N, Rashidi I, Mombeini A. Hepatoprotective activity of Capparis spinosa root bark against $\mathrm{CCl} 4$ induced hepatic damage in mice. Iran J Pharm Res 2007; 6(4):285-290.

8. Muhaidat R, Al-Qudah MA, Al-Shayeb A, et al. Chemical profile and antibacterial activity of crude fractions and essential oils of Capparis ovata Desf. and Capparis spinosa L. (Capparaceae). Int J Integr Biol 2013; 14(1):39.

9. Okur ME, Ayla Ş, Çiçek Polat D, et al. Novel insight into wound healing properties of methanol extract of Capparis ovata Desf. var. palaestina Zohary fruits. Journal of Pharmacy and Pharmacology 2018; 70(10):1401-1413.

10. Ergur BU, Gazioglu I, Sen A, et al. Capparis ovata treatment suppresses inflammatory cytokine expression and ameliorates experimental allergic encephalomyelitis model of multiple sclerosis in C57BL/6 mice. J Neuroimmunol 2016; 298:106116.

11. Arslan R, Bektas N. Antinociceptive effect of methanol extract of Capparis ovata in mice. Pharm Biol 2010; 48(10):1185-1190.

12. Arslan R, Bektas N, Ozturk Y. Antinociceptive activity of methanol extract of fruits of Capparis ovata in mice. J Ethnopharmacol 2010; 131(1):28-32.

13. Tlili N, Elfalleh W, Saadaoui E, et al. The caper (Capparis L.): Ethnopharmacology, phytochemical and pharmacological properties. Fitoterapia 2011; 82(2):93-101.

14. Gull T, Anwar F, Sultana B, et al. Capparis species: A potential source of bioactives and high-value components: A review. Industrial Crops and Products 2015; 67:81-96.

15. Beretta G, Facino RM. Recent advances in the assessment of the antioxidant capacity of pharmaceutical drugs: from in vitro to in vivo evidence. Analytical and Bioanalytical Chemistry 2010; 398(1):6775

16. Wang Y, Simar D, Fiatarone Singh MA. Adaptations to exercise training within skeletal muscle in adults with type 2 diabetes or impaired glucose tolerance: A systematic review. Diabetes/Metabolism Research and Reviews 2009; 25(1):13-40.

17. Paşayeva L, Özalp B, Fatullayev H. Potential enzyme inhibitory properties of extracts and fractions from fruit latex of Ficus carica-based on inhibition of $\alpha$-amylase and $\alpha$-glucosidase. Journal of Food Measurement and Characterization 2020; 14 (5):2819-2827.

18. Gyamfi MA, Aniya Y. Antioxidant properties of Thonningianin A, isolated from the African medicinal herb, Thonningia sanguinea. Biochem Pharmacol 2002; 63(9):1725-1737.

19. Devasahayam G, Burke DJ, Sturgill TW. Golgi manganese transport is required for rapamycin signaling in Saccharomyces cerevisiae. Genetics 2007; 177(1):231-238. 